\title{
Company brokers: \\ Human resources \\ managers in foreign \\ mining projects in the \\ Congolese Copperbelt
}

Ethnography

0 (0) $|-2|$

(C) The Author(s) 2020

Article reuse guidelines:

sagepub.com/journals-permissions

DOI: 10.1177/146613812094891।

journals.sagepub.com/home/eth

@SAGE

\section{Benjamin Rubbers (D)}

Faculté des Sciences Sociales (B3I), Université de Liège, Liège, Belgium

\begin{abstract}
Based on ethnographic research between 2016 and 2018, this article examines the role of Congolese HR managers working for the transnational companies that have developed new mining projects in DR Congo's copperbelt over the past two decades. Drawing inspiration from the anthropological literature on brokerage, the analysis proposes to study this category of middle managers as company brokers, who derive power from their ability to control access to jobs in foreign companies and who take on an active role in the organizational changes that new investors put in place. In developing this line of analysis, the article's aim is to understand how mining capitalism is mediated from within foreign companies. In this view, mining projects are not only negotiated by brokers in the local political arena, they are themselves co-produced by the local workers they employ.
\end{abstract}

\section{Keywords}

Human resources, brokerage, mining, multinationals, capitalism, Congo, Africa, middle managers

\section{Corresponding author:}

Benjamin Rubbers, Faculté des Sciences Sociales (B3I), 3 place des Orateurs (B3I), Université de Liège, 4000 Liège, Belgium.

Email: brubbers@uliege.be 
"Are we in South Africa or in the Congo here?", Alistair asked himself after working for a few months in a global mining company.1 We were sitting on the terrace of his house on a Sunday afternoon, and he was telling me about his experience as a Congolese Human Resources (HR) manager in this company. Although he held a senior management position, he was being confronted by informal racial segregation practices in the workers' camp where he lived for three weeks each month. At work, his South African supervisor retained all the powers and privileges, yet it was Alistair who was under pressure from all sides to hire workers. During our conversation, he received two phone calls, one from a member of the national parliament, and another from an army general, both offering up candidates who could be suitable for a job in his company. Alistair was also put in the position of defending his employers' interests before the unions, and justifying mass layoffs to political authorities. Last but not least, he was the person the workers held responsible for the company's decisions. He often worried about his safety and it seems that his fears were founded: When I met one of his friends a month later, he told me that Alistair had fled to Zambia with his family. After the company announced a restructuring plan, he had received an anonymous threatening letter. ${ }^{1,2,3,4}$

The contradictions Alistair confronted at work have their roots in the liberalization of the Congolese copper mining sector and the boom in foreign investments that followed in the 2000s. Throughout the 20th century, this sector was dominated by a single enterprise - the Union Minière du Haut-Katanga (UMHK), renamed Générale des Carrières et des Mines (Gécamines) after its nationalization in the late 1960s (Dibwe Dia Mwembu, 2001; xx, 2013). The company built infrastructures and developed social programmes that allowed it to take charge of all aspects of its workers' lives. Following its decline in the 1990s, the state-owned enterprise began to seek foreign partners to operate its mines and plants. Stimulated by the generous tax conditions offered by the mining code promulgated in 2002 and the rise of copper and cobalt prices from 2004 onwards, investors of various sizes and origins came to explore the opportunities available to them in the Congolese copperbelt, and start new mining and industrial projects - most of them in joint venture with Gécamines. A dozen projects are currently in the production phase. In several respects, the labour practices put in place in these projects break with those upheld by Gécamines in the past: the new companies hire fewer workers, grant less benefits, and do not hesitate to terminate contracts for economic reasons ( $\mathrm{xx}$, 2019). It is against this background that the difficulties Alistair encountered in his job as a HR manager must be understood, as he has come to represent a foreign company that seeks to drastically cut labour costs in a region profoundly marked by the legacy of Gécamines' industrial paternalism.

This article aims to analyze in more detail the role of HR managers working for the transnational companies that have developed new mining projects in the copperbelt over the past two decades. Middle managers working for transnational companies in the global South are seldom taken as an object of investigation in the social sciences. In the study of mining companies, classical ethnographies 
focused on the consciousness of unskilled workers (Finn, 1998; Gordon, 1977; Moodie and Ndatshe, 1994; Nash,1993[1979]); only recently have researchers started paying attention to the practices of expatriate executives (Rajak, 2011; Welker, 2014). Yet national middle managers often play a key role in the implementation of strategic changes locally and the localization of foreign companies (Golub and Rhee, 2013). Studying their role can therefore contribute to a better understanding of the development of mining capitalism in the global South.

There are now a number of qualitative studies on middle managers (Dalton, 1959; Hassard et al., 2007, 2009; Ho, 2009; Jackall, 1988; Kunda, 1992; Watson, 1994). Most of them, however, are based on research in long-established companies of the global North (especially the US, UK, and Japan) and their main focus is on power relations in the organization, the promotion of corporate culture, and the experience of middle managers confronted to restructuring processes. Although this body of literature provides insights on the internal workings of corporations, including mining corporations (see xx, 2020), it does not allow to capture the specifics of the work performed by middle managers employed by recently established foreign companies in the global South - how they get their job and access their position; how they obtain and maintain expatriate executives' trust; and how they participate in the implementation of corporate policies at the local level.

To study the work of these middle managers, this article proposes to draw inspiration from the social science literature on brokers and brokerage. Brokers are broadly defined in this literature as intermediaries who draw material, political, and symbolic profits from mediating the access to resources they do not control in contrast to patrons, who directly control the resources that are redistributed in the community (Lindquist, 2015: 870; see Blok, 1969; Boissevain, 1974; Mayer, 1967). Their work of mediation is generally understood as being at the same time delicate - brokers must deal with conflicting expectations - and profitable brokers can influence the course of events to their own advantage. While doing so, it also contributes to reconfigure power structures locally - brokers are key agents of social change (Bailey, 1963).

There are however different types of brokerage, and these variations deserve more attention from social scientists (Stovel and Shaw, 2012; Swidler and Watkins, 2017). In line with classical studies in the anthropology of brokers, recent ethnographic studies continue to focus on the role of local power figures in projects implemented by external organizations in rural areas (Bierschenk et al., 2000; James, 2011; Mosse and Lewis, 2006). The literature on new mining projects is no exception to this tradition (e.g. Cuvelier and Geenen, 2019; Manson and Mbenga, 2003; Negi, 2010). This bias in favor of local brokers inadvertently leads to neglect the way in which mining projects are negotiated by different categories of actors within foreign companies: these companies continue to be represented in most of these studies as corporate persons with their own will (see, for a critique of this view, Ballard and Banks, 2003; Golub, 2014; Welker, 2014). If the anthropological literature on brokerage allows to break with the romantic image 
of the isolated, consensual, village community, it does not really challenge, on the other hand, the monolithic image of the mining corporation as a profit-oriented machine.

To balance this asymmetry, this article proposes to show the relevance of the anthropological literature on brokerage for studying the role of middle managers in transnational mining companies who work at the interface with local stakeholders. Mining projects bring many resources locally - taxes, markets, jobs, gifts, social investments, and so on -whose allocation is generally managed by various professionals. The number of these professionals depends on the size of mining projects. While in small projects, or in large projects in the development phase, all the administrative and social functions (personnel management, public relations, legal affairs, community development, etc.) are often performed by the same Congolese manager, in larger projects, they are divided among different departments, services, and professionals. In any case, these middle managers can be viewed as company brokers, who facilitate the establishment of projects in the local political arena and draw various personal benefits from this work of mediation. 2 In doing so, this paper argues, they contribute to shape mining capitalism at the local level.

In the following sections, I will focus on three specific dimensions of the brokerage work carried out by HR managers in the Congolese mining sector: the skills that they must develop to perform this work, their struggle for gaining expatriate executives' trust, and their role in the changes that new mining investors have brought in the domain of labour. The data used for this analysis was collected during ethnographic fieldwork carried out between 2016 and 2018 within the framework of the [details about the research project and the funding body $\mathrm{xx}$ ]. During this period, I completed a one-month internship in a mining company's HR department and conducted more than one hundred interviews with various actors involved in the regulation of work in the Congolese mining sector. Below I principally use the long, repeated, conversations that I had with HR managers in the mining sector.

\section{Skills}

To act as intermediaries between external organizations and local communities, brokers must master different linguistic and cultural codes, and be able to change from one to the other according to circumstances (Cohen and Comaroff, 1976; Geertz, 1960; James, 2011). To bring to light the brokerage work carried out by HR managers therefore implies to begin by studying the various skills that they put to use, and analyzing how they developed these skills during their careers (Bierschenk et al., 2000).

The HR managers working for foreign mining companies in the Congolese copperbelt have common social characteristics. First, they are Congolese nationals, as the position of personnel manager being on the list of occupations foreigners are forbidden by law from holding. Second, they have a higher education degree 
from a Congolese or foreign institution. And third, they are predominantly men. I could find only one exception to the latter, a woman who had been appointed by Gécamines as HR manager in a joint venture project with a Chinese state-owned enterprise, who, unfortunately, refused to meet with me. According to my informants, if most HR managers are men, this is above all because this job requires to have authority over the workers, who are predominantly men. Men, they explained to me, are more prepared to exercise such authority and are also ascribed more legitimacy for such authority in the eyes of workers. Independent of these common characteristics, three typical careers, or modes of access to the position of HR manager, can be distinguished.

The oldest HR managers worked for Gécamines before being appointed to a new mining project. Most mining projects in the Congolese copperbelt are based on joint venture agreements, which provide that appointments to certain managerial positions are the prerogative of the Congolese state-owned enterprise. Generally, Gécamines management identifies a candidate from its senior managers who are close to the end of their career, and are hired with a new contract by the joint venture project. Since the new position comes with a raise, most managers accept the job offer with enthusiasm. In their view, it is a kind of golden parachute, that allows to save some money before retirement. A small number of HR managers were recruited by the mining company shortly after graduating from university, and progressively rose to the position of HR manager in the organization. The last category of HR managers is distinct from the previous one insofar as they have worked for several multinational companies before being recruited for the job they currently hold. From position to position, and company to company, they improved their English, developed relationships with some expatriate executives, and raised their profile on the labour market.

Whether they studied in the Congo or abroad, none of my informants had been trained as a HR manager. Having obtained their degree in law, economics, sociology, or another subject, they acquired their professional HR skills on the job. These include organizational skills (mastering the rules and procedures for recruitment, the calculation of wages, disciplinary actions, dismissals, etc.); legal skills (knowing the labour law sufficiently to negotiate with unions, to prevent penalties from labour inspectors, and to avoid workers taking legal action against the company in case of mass layoff); and, in some cases, strategic skills (some HR managers are invited to actively participate in the implementation of organizational development plans designed by the joint venture majority partner's HR team at the headquarters). Independently of these professional skills, HR managers must of course develop various linguistic, social, and cultural skills in order to tactfully manage the contradictory interests of executives, union representatives, workers, and local state authorities.

While my informants learned the foundations of their trade on the job, they also had the opportunity to participate in training courses in the Congo or abroad. Some companies offer HR managers accelerated training courses in a neighboring country. Additionally, the national employers' association regularly organizes 
courses on various HR rules and procedures in Lubumbashi. These are taught by Congolese experts who are also occasionally hired as HR consultants by mining companies. Conscious of gaps in their training and knowledge, several of my informants told me about their plans to complete a master's degree in HR management in South Africa or in Europe. In doing so, they hope to augment their experience with a degree from an internationally recognized institution and advance their careers - for instance, by gaining access to a HR position at a multinational company's headquarters. Finally, a group of HR managers took the initiative to organize themselves by creating a WhatsApp group on which they discuss about the problems they face in their day-to-day work.

This attraction to theoretical training, and more particularly to diploma courses, suggests a common aspiration toward professionalization among HR managers. As the subject matters of the training courses they complete indicate, their strategy for professionalization is built on legal expertise and organizational development. It is principally these two skills - along with a command of the English language - that HR managers use to define their professional identity and rank each other. First, as an expert in labour law who has worked as a consultant for several mining projects explained to me, whether it is in the calculation of wages, job classification, or dismissal procedures, all mining projects established in the copperbelt have made legal errors, exposing foreign investors to serious legal, financial and/or social problems. The HR managers I interviewed blamed their predecessors' amateurism for such errors and, in order to highlight their own legal expertise, explained how they resolved them. Second, the HR managers involved in implementing organizational development plans also distinguish themselves from those managers whose functions are limited to personnel administration (pay calculation, leave management, etc.) in the tradition inherited from Gécamines. Building on their work experience in several multinational companies, their command of English, and their international social network, they were eager to demonstrate their knowledge of the latest fashion in strategic HR management (flexible career development, extensive use of IT tools, the promotion of workers' participation, etc.).

Of course, the opportunity to develop these professional skills depends heavily on the size of the company for which HR managers work. In small mines, and large mining projects in the development phase, HR managers are usually employed as multipurpose local assistants, who take in charge all the legal, administrative, and social aspects of personnel management. As these projects are often autocratically managed by an expatriate general manager for whom personnel management is often the least of his concerns, it is usually in these situations that violations of the labour law (absence of work contracts, unfair dismissals, refusal of unions, etc.) are most common. No matter how skillful HR managers are: In the face of their boss' decisions, they cannot do much except attempt to find retroactive solutions to the problems they pose.

As mining projects develop, and begin to have a larger permanent staff, HR managers have the opportunity to delegate specific tasks (recruitment, discipline, industrial relations, etc.) to collaborators. Their own job increasingly consists of 
supervising these collaborators' work and reporting to the project's general manager. Generally speaking, as medium-sized and large companies in the production phase have put in place rules and procedures in compliance with the law, they have much better organized HR management apparatus than smaller companies. Such structures are nonetheless to a large extent still limited to bureaucratic procedures similar to those used by Gécamines' personnel department in the past. It is only recently, following the decline of copper prices in 2011, that some multinational companies have adopted new organizational development plans that follow a more strategic approach to HR management. These plans are very similar from one company to another: they aim to optimize the organizational chart, to standardize rules and procedures, and to develop new IT management tools. On the other hand, they are not very participative: Congolese workers have few opportunities to get involved in the decision-making process and/or to be promoted to executive positions. The logic behind the organizational innovations implemented in these companies is still largely top-down, bureaucratic, and coercive, i.e. they are largely based on control and discipline.

Most of my informants, who are already among the highest ranked, the most influential, and the best paid Congolese managers, feel that they have reached the ceiling. The only advancement opportunities open to them are to find employment in a larger mining project, or move beyond the project level, at the headquarters of a multinational company. Moreover, they are keenly aware of being in a precarious position: for whatever reason, they told me, they could lose their job overnight. Unsurprisingly, this situation was often contrasted with that of Gécamines managers in the past, who had both strong job security, and various advancement opportunities in the state enterprise's large bureaucratic structure.

To cope with the uncertainty inherent to their job position, HR managers develop various strategies. On a day-to-day basis, aware that the preservation of their job depends on expatriate executives' goodwill, they strive to maintain their trust. As we have seen, some HR managers seek to make their future more secure by following distance learning courses in a recognized foreign institution. They hope that the degree that they will obtain from this institution will give them the opportunity to get a better job in case they are dismissed. Finally, even though their job is generally time-consuming, many HR managers have developed small businesses on the side, that they manage at a distance: Peter took over his father's construction company; James buys real estate to rent; Steven has bought land to farm; Patrick has created a security company with a South African associate; etc. Given the insecurity Congolese people confront, "looking for money" by developing various parallel activities has become the only game in town, including among those who earn high wages.

\section{Trust}

Since the pioneer studies of customary chiefs in colonial Africa (Fallers, 1955; Gluckman et al., 1949; Kuper, 1970; Mair, 1936), the anthropological literature 
on brokers has highlighted the dilemma they face as they are confronted to conflicting expectations from external institutions and local communities. Characteristic of brokerage in general, these conflicting responsibilities explain why brokers are often suspected of taking advantage of the situation, and why they are generally in a precarious position: their legitimacy to control access to resources they do not have is quickly put into question from all sides. To maintain their position, brokers must spend considerable energy to cultivate the trust of all stakeholders. This trust-building work varies however according to the balance of forces and the opportunities that the different parties can offer to brokers. In the case of Congolese HR managers, who are employed by mining companies, the most important is to get into expatriate executives' good graces. As we will see in the next section, this bias in favor of expatriate executives can have serious consequences in their relationship with other Congolese workers.

As we have already seen, the position of HR manager, which foreigners are forbidden from holding, is one of the highest positions Congolese workers have access to in the mining sector. In most mining projects, HR managers report directly to the general manager, have a seat on the board of the heads of department, and occasionally participate in meetings with the majority joint venture partner's HR team at the headquarters. This does not mean, however, that they are considered full members of the senior management team. First, as they run a small department considered to be of minor importance, HR managers must often struggle to have their voices heard in the company. For obvious reasons, the project's general manager gives priority to the needs of departments involved in the production process. As a result, the heads of these departments tend to make decisions about their staff (to impose their candidate during the recruitment process, to transfer a worker from one service to another, or even to dismiss a worker, etc.) independently, and to use the HR department as a mere execution service responsible for formalizing their decisions. The power of the HR manager depends closely on the prerogatives that the project's general manager is willing to give him.

Second, HR managers are not part of the expatriate executive staff, who are directly recruited by the majority joint venture partner's head office. Consequently, they have very limited power over the members of this higher caste, unless they commit a serious offense against a Congolese worker, which is subject to disciplinary action by the HR department. An unwritten rule stipulates that HR managers are exclusively responsible for the national workforce from which they themselves originate.

Finally, in some companies, the foreign joint venture partner appoints an expatriate Organizational Development Officer (ODO) who oversees the Congolese HR manager's work. The latter finds himself placed in a situation analogous to that of the black personnel officer described by Burawoy (1972) during Zambianization in the 1960s. It is the expatriate supervisor who reports to the project's general manager, who sits on the board of the heads of department, and who participates in strategic meetings at the headquarters abroad. Although the Congolese HR manager has the title of a (senior) manager, and receives a relatively high salary, his 
actual role is to a large extent reduced to legal advice and red tape. This is, of course, a frustrating experience:

"The ODO does not have any experience", a HR manager in this situation told me, "You feel embarrassed when you talk to him, you must lower yourself to his level, and when you give him ideas, he takes them and then presents them as if they were his own ideas. This is very frustrating, you know. I'm the HR manager, but I'm not given any real value. They don't listen to me. They take me for a suspect person, who'll give all the information to workers, or to state authorities"

One of the reasons for this relative marginalization is that expatriate managers make a separate social world, from which Congolese HR managers are to a large extent excluded. The expatriates have a closer relationship with each other as they come alone to the Congo, and share the same language and interests. Even when they live together with Congolese workers on site, they tend to stick together after working hours. For Steven, who lives in a camp with his family for ten years, this is a "natural" situation:

"Racism is absolutely natural, it's normal. When you're with another white, you feel part of the same world, and me too, when I'm with my black brothers, I feel comfortable. There are things that we can't do together. Let me take the case of the camp where I live: The South Africans, on week-ends, they are used to make braais [barbecues], but me, my own culture, is to go cultivate my field. On both sides, there is a different culture"

As this quotation suggests, far from castigating it as the remnants of a colonial racism that no longer has a place in the Congo, the HR managers I met tended to show leniency towards expatriates' discrimination practices. They understood it as the result of a difference of culture and/or of a comprehensible distrust of Congolese people. The idea that the Congolese people are untrustworthy is, indeed, widely shared in the Congolese copperbelt (xx, 2009). During a conversation in a fancy bar in Kolwezi, Daniel accordingly justified the dominance of expatriates in the mining sector with the bankruptcy of Gécamines, which demonstrated in his view the Congolese people's failure to develop their country's mining potential:

"When they came here, they [foreign investors] found a country with all its riches. Minerals are easy to take here. It is not like Chile, or Siberia, where the nature of the soil causes serious problems for mining companies. So they came here and realized that Congolese people haven't been able to extract these resources, are unable to do it. They inherited a large company like Gécamines from the colonizer, but it collapsed. You understand? Trust disappears straightaway. If you give these people responsibilities, you risk losing your investment. So, you have a strong lack of trust in the national staff. This can be seen in the company in the lack of access to important 
positions. I'm of course among the Congolese workers in a high-ranking position, but this is admittedly due to the fact that the law provides that the HR manager must be a Congolese. For other positions, there is no such legal provision, and the company prefers to appoint expats. It can't take a local."

According to sociologist K. Renner (1978[1953]; see Bouffartigue and Gadéa, 2001; Goldthorpe, 1982, 1995), managers constitute a 'service class' whose power in organizations depends on the employer's trust in their capacity to work in his/her best interests. In contrast to workers, who are hired for their labour power, the employment relationship with managers is based on a code of service, which involves an important degree of trust. Since trust is never given in advance, managers must constantly show that they deserve it. In the case of mining companies, the choice to hire expatriates for key positions is as much based on trust as on professional proficiency. After all, they speak the same language, they have a recognized degree, they know the same people, etc. Congolese HR managers, by contrast, are a priori subjected to suspicion: Are they able to do the job? Do they draw personal profits from their position? Are they on the employer's or the workers' side? If expatriate executives are generally willing to give them a chance, the slightest mistake on their part will be sufficient to break the trust they have placed in them and could lead to their disgrace.

The stories of HR managers' careers in the mining sector can be read as a struggle to gain expatriate executives' trust and to legitimize their full membership in the managerial class. During interviews, many managers explained in detail how they obtained their job: they showed that they had the skills for the job by pointing out weaknesses in the existing HR management and proposing the necessary solutions to improvement. They also drew attention to the concrete actions they had taken since they held the position to formalize procedures and bring them into line with the law. Cutting staff was presented as a particularly critical test of their capacity to take on the role of HR manager. Those who had to organize mass layoffs following the financial crisis of 2008, or the decline of copper prices in 2011-2016, stressed the complex and sensitive nature of the course of action that they had to follow. Finally, and perhaps most importantly, my informants pointed to the importance of demonstrating their loyalty to the company during union negotiations, by defending its interests in the best possible way in the face of workers' demands.

Showing loyalty to the company during union negotiations brings about two difficulties. First, ex HR managers, who have at times themselves contributed themselves to the introduction of unions in the company, do not hesitate to justify their presence: union representation is required by the law; union's approval is compulsory to take certain internal organizational measures (the promulgation of staff regulations, the adoption of a collective agreement, the creation of a health and safety committee, etc.); and, last but not least, unions can be useful in preventing work stoppages or strikes. But expatriate executives, they told me, have trouble understanding that, far from being some hardline militant organization, Congolese unions are the company's "partners", who can contribute to industrial 
peace. Since the colonial era, their role has been to "educate the working class", an expression by which my informants mean to sensitize unskilled workers to the requirements of industrial work and to prevent the spread of false rumors among them. In their view, it is when the HR department and its union partners fail in fulfilling this mission that (uneducated) workers go on strike.

For HR managers, to allow the union delegation to achieve its educational role, it is essential that union representatives be united and responsible. Competition between them, and/or the presence of "extremists" among them are considered as factors that increase the risk of wildcat strikes. In order to have a "good" union delegation, HR managers do not hesitate in interfering with union elections, and paying high attendance fees for union meetings. They also take care to show union representatives respect and to meet at least some of their demands. As the HR manager of a large company explained to me, contrary to what some expatriate executives think, being rude to unions is not a good strategy: "The Congolese are like donkeys, if they're beaten, they take a stand and don't move anymore".

The second difficulty is that most expatriate managers do not understand what is being said at the bargaining table because they do not speak French. It is the HR managers who deal directly with union representatives on behalf of the employer, and then report to their expatriate superiors. The problem here is that they also benefit from the improvements obtained by the unions: "We are also employees, and we have dependents", one of them told me, "so if the company increases school allowances, we will not be opposed to it". In addition, contrary to expatriates, HR managers know the expenses that workers face in their daily lives, and thus find many of their demands to be rather reasonable.

All the HR managers I met nonetheless unanimously stressed that their role is to defend their employer's interests against those of unions and workers. Their job demands it. Using a sports metaphor, they explained that, in the match opposing the employer to the unions, they are "on the employer's bench". The fact that they have the same background as the opposing team, and that they share their condition, should not prevent them from playing on the side of the visiting team without cheating. As Steven explained:

\footnotetext{
"The general manager once told me: 'you seem to be more union than employer. So it had kind of upset me. It must be said: I'm already in the management team, I'm on the employer's team, I'm the employer, so I wish no one could tell me that I'm also a unionist. Because many times, I have held the union meetings without the general manager. You see, I'm conducting the meetings, I'm communicating to the unions, I'm deciding on behalf of the employer. I understand very well the difficulties on the union side because I share the same realities as all the other Congolese. But to say that I'm in collusion with the unions because the employer is an expat, I don't think so. If that were the case, I would not understand my role. The truth is that I'm HR"
}

To demonstrate their skills and loyalty to the expatriate executives is not everything. For HR managers to gain their trust and justify their presence in the 
managerial team, they must more broadly make a good impression on their expatriate bosses (see Gonzales, 1972). According to the folk sociology of the different corporate cultures that HR managers have developed over the past decade, this 'face work'- which requires specific social and cultural dispositions - depends on whether they work with the "Anglo-Saxons" (a category including the "Americans", the "South Africans" and the "Australians"), the "Belgians" and the "French", or the "Chinese". These nationalities are those of the project's expatriate directors. It is not necessarily correlated with the country where the parent company has its headquarters.

Take for instance the case of companies run by "Anglo-Saxon" executives. In these companies, HR managers must show that they work hard by arriving early and leaving late, and by being reachable at all times including outside working hours. They must also understand the subtlety of the interaction codes that prevail among this category of expatriates. The ability to speak English is of course essential, not on only as a medium for communication, but also as a sign of intelligence (see Kalonji Wa Mpoyo, 2016). As a friend who worked as a consultant in several multinational companies told me, "If you don't speak English, the expats see you as an idiot who is unable to think". It is also appropriate to be assertive and jovial with the Americans, the South-Africans and the Australians as they are perceived as being less formal than the "Belgians" and the "French" who worked at Gécamines in the past (see, on the etiquette prevailing in large American corporations, Jackall, 1983) [AQ3]. At the same time, Congolese HR managers quickly learn that this apparent familiarity does not mean that they can afford to interrupt their superiors, to give their opinion freely, or to take the lead in the conversation they are not an equal footing. Finally, as we will see below, some of my informants consider prudent to distance themselves from the industrial paternalism of Gécamines during exchanges with expatriates as a means to show that they are favorable to the development of a new ("Anglo-Saxon") corporate culture centered on value creation (production, downsizing, outsourcing, participation, etc.).

HR managers' command of the codes governing the interactions with expatriates can be understood as a form of cosmopolitanism in Hannerz's (1996: 102-111) sense of the word. Of course, even though they occasionally travel abroad, they are locals at heart in many ways. Their social and cultural life outside working hours principally revolves around the family, the church, and their private businesses. Only a few go to fancy bars and restaurants. In a way, however, HR managers are more cosmopolitan than the expatriates working in the mining sector, who live in secure compounds on site or in town without expending much effort to learn the local languages, or to know more about Congolese culture. Indeed, they show two characteristic features of Hannerz's 'cosmopolitan attitude': a certain openness to expatriates' cultural differences, on the one hand, and a critical distance from certain aspects of their own local culture, on the other. Far from reflecting a general stance towards cultural difference, this cosmopolitan attitude must be understood in the light of their job's requirements, which have changed considerably since the arrival of new foreign investors in the early 2000 s. 


\section{Mediations}

Brokers are not vectors who merely implement programs of action designed elsewhere. On the contrary, they contribute to shape these programs by translating the interests of the different parties involved, mobilizing them around common goals, and channeling the distribution of resources among them (Mosse and Lewis, 2006). In other words, their agency makes a difference in the way programs of action are put in place locally. The HR managers are no exception; they have been actively involved in the changes that new mining investors brought in the domain of labour in the Congolese copper mining sector.

The first thing that struck HR managers coming from Gécamines was the small size of the new companies, especially the department that they had to run. Gécamines' personnel administration, which had more than 34,000 workers under its supervision in the early 1990s, was a large bureaucracy with a head office in Lubumbashi and decentralized services in the company's various subdivisions. In comparison, with a permanent staff not exceeding 4,000 workers, the HR departments of the new companies are very small. For example, while 30 people worked in the recruitment division at the Gécamines head office in the past, this function is now performed by only one person. Although they oversee a smaller team, HR managers in the new mining projects are directly involved in the supervision of a larger number of functions or task domains. As John, who had worked in the Gécamines administration in Kolwezi for a long time before starting a career in various foreign companies, explained:

\footnotetext{
"Now, I feel more responsible. What does it mean? The former HR functions are still there, but there are also other things that I was not doing in the past. (...). It's a total domain of responsibility that the company gives you, from the worker's recruitment to his departure. For instance, when I began to work at the Gécamines' personnel management office in Kolwezi, we were not responsible for recruiting workers. Recruitment was managed from the Lubumbashi head office. For the payroll, we were responsible for the time sheets and pay slips at the end of the month, but only for the workers, not for the managers who were directly supervised from Lubumbashi. With the new management here, the HR department is responsible for it all, from the selection of workers to the calculation of bonuses and benefits, for both the workers and the managers".
}

If Gécamines workers like John left Gécamines, it is because the new mining companies offered them a higher, more regularly paid, salary. Eroded by inflation, the salaries of Gécamines workers were low and, from the late 1990s onwards, was paid erratically. Up to the 1970s, they considered that this low wage to be compensated for by the various benefits they received from the company (a house, family food rations, free access to schools and hospitals, and so on). But after the company sold its houses to the workers and began to cut in social expenditures, these benefits lost much of their importance. In 2003, Gécamines workers had on 
average more than 36 months of wage arrears and no substantial additional benefits. Thus, workers, like Lester, who had the opportunity to get a job in a new mining company did not hesitate to take the new opportunity: "What attracted me here [in the company where he is currently employed] is that when you work here, you receive a salary. You are given money to live decently, which is different from Gécamines. When I was called for the interview, I asked: 'How much do you want to pay me?'. 'That much' [they answered]. 'All right! I'm coming right now'”.

On the other hand, reluctant to reproduce Gécamines paternalism, most of the new investors reduced the number of benefits workers were offered and converted those that they continued to provide in cash. While this mode of remuneration (in cash) might be preferred by workers, it has led to wages- especially among unskilled workers - that are insufficient in covering all their expenses (rent, school fees, etc.). In all mining companies, unions demand higher wages and do not hesitate to use Gécamines model to do so. Drawing inspiration from the stateowned enterprise's collective agreement, they ask for an increase and/or an extension of the legal and extra-legal benefits included in the calculation of their wages (distribution of sacks of maize flour, contributions to school fees, etc.). They also propose the introduction of a rank and salary scale that workers could climb by gaining in seniority or completing training. Currently, the only opportunity to rise in the hierarchy and/or to benefit from a salary increase is to apply for higher position internally or to take a job in another company.

Under these conditions, the expatriate management instructs HR managers to explain to the unions that their demands are both disproportionate and obsolete. As mining projects are still in the development phase, and pushed to demonstrate their profitability to shareholders in the short term, they cannot afford to prioritize the workers. More fundamentally, to meet their demands would lead to reproducing an outdated paternalistic model - a model that is at the root of Gécamines' economic failure in the view of foreign investors. It is up to the unions to understand that their duty is now to preserve jobs by explaining to workers that they must get by with the wages they receive. In all circumstances priority must be given to the company's cost-effectiveness and to the creation of value.

The recruitment process in new mining companies is not very different from the one in place at Gécamines since the late 1960s. The main difference is that recruitment is not organized by a large bureaucratic machine, but by small teams under the direct supervision of HR managers. The latter are, for this reason, under strong social and political pressure. In a country where the number of higher education graduates is constantly increasing, even though "proper" jobs remain extremely scarce, mining companies receive a very large number of applications. Most of these applications are accompanied by recommendations from moral or political authorities to the HR manager personally (Kahola, 2015). For most Congolese people, the HR manager is the foreign company's "gate". After all, it is to him that application files must be sent, and his department is responsible for selecting the candidates who will make it to the second step of the process, the tests and the interview. Although he does not have the last word (it is the head of the recruiting 
department who makes the final choice), he has the power to put CVs on top of the pile. As we have seen above, HR managers are also among the top-ranking Congolese managers in the company. Unlike expatriates, their phone number is easy to find, they speak French, and they are able to gauge the importance of the candidate's sponsors. Above all, they are used to recommendations as they are an integral part of institutional life in the Congo.

The HR managers I encountered were indeed quite lenient with the constant recommendations they received from all sides: relatives, neighbors, colleagues, church members, friends from university, customary chiefs, political parties, and various state authorities, from the local to the national level. These recommendations were made orally, by phone, or by letter. Faced with these multiple requests, their strategy is always the same: they systematically answer that the recommended candidate's CV will be seriously taken into consideration and that the sponsor will be informed of the application's outcome. Even if they do not take recommendations into account, it is essential for HR managers to show their good will to their interlocutor. If they were to explicitly ignore these recommendations, they would unnecessarily expose themselves not only to criticism from their entourage, but also to threats from powerful people.

This last risk is particularly important for HR managers who are not "originaires" (autochthonous) of the territory or the province where the mine site is located. ${ }^{3}$ Most mining companies established in remote rural areas adopt local content policies within the framework of their CSR program - another innovation in comparison to Gécamines policies in the past. For recruitment, HR managers are expected to give priority to candidates from local communities and to pay particular attention to recommendations from local power figures. However, this rule is only followed for unskilled jobs, which are rather limited when mining projects are in the production phase. Under these conditions, HR managers who are "non-originaires" are swiftly accused of favoring those from their fellow tribe/province to the detriment of local communities (see Geschiere and Nyamnjoh, 2000). With the support of customary chiefs, local ethnic associations such as Sempya (Bemba) or Lwanzo lwa Mikuba (Sanga) do not hesitate to send letters to the company, to protest and/or to ask state authorities' support in demanding the dismissal of the HR manager. Although these efforts rarely achieve their goals, they lead mining companies to consider hiring a candidate from the appropriate tribe or province when the HR manager position is left vacant in the hope of avoiding unnecessary tension with local communities.

Finally, the new mining companies offer more precarious jobs than Gécamines. In comparison to the state-owned enterprise, workers in these companies are more readily dismissed for gross misconduct, and calls to a political patron to be rescued from disciplinary action are less effective. Although the number of dismissals for disciplinary reasons should not be overestimated, the number of punishable behaviors, the increased punishment for such behaviors, and the inflexible attitude of management contribute to fueling workers' sense of precariousness. In addition, following the financial crisis in 2008, and then the decline of copper prices between 
2011 and 2016, several mining companies cut their workforces through mass layoffs, voluntary departure programs, or technical leave procedures. Justified by the necessity to keep their finances - if not, their stock price - afloat, such practices contrast the stability of employment Gécamines provided in the past. In the 1990s, even while it was going into debt, it did not dismiss any worker.

As HR managers are responsible for prosecuting and dismissing the workers guilty of misconduct as well as for preparing the list of those who will be impacted by a mass lay-off, this new political economy of precarious employment has important consequences for them. Following a logic similar to that observed for recruitment, they are suspected to have discretion in these procedures, and they are thereby subjected to multiple pressures from within and outside the company. Those who fear losing their jobs do not hesitate to ask state authorities to exert pressure on the HR manager and/or to directly threaten him. Such personal threats have led some HR managers to take strong measures to protect themselves and their families. Steven, who fears being attacked, no longer eats outside his house, and only leaves the mining concession in the company of an armed policeman. After some workers took their issues with the mining company out on his children, Daniel decided to send them to school in South Africa, where they now live together away from their parents. And Alistair, with whom I introduced this article, moved his family to Zambia after receiving a threatening letter.

Several informants referenced the assault of the Air France HR manager in 2015, whose video had widely circulated on news channels, to suggest that their job is by definition "unpopular" across the globe. The dialectics of requests and threats progressively push them to avoid contact with colleagues and to limit their social life outside work to their family and the church. If they go out, it is only in fancy places frequented by the rich. As a result, they are often seen by workers as cold, arrogant, men, who have broken with the social world from which they come. In a sense, HR managers could be viewed as the counterpart of Simmel's (1950[1908]) "stranger". Unlike the stranger, they are "organic" members of the group "from the beginning". At the same time, as they serve foreign interests, they are caught in an "estrangement" process. By virtue of their duties, they are progressively put at a distance from the group, and the relations with them come to integrate an element of coolness, some skepticism about his attachment to the group.

It is clear from the above that, even though their room for manoeuver varies according to the size and the development phase of mining projects, Congolese HR managers do not only endure organizational changes designed elsewhere. They actively participate in their implementation at the project level: they justify the employer's decisions; they negotiate unions' demands; they ensure that the company complies with the law; they maintain good relations with state authorities; they intervene in the selection of job candidates; and so on. This work of translation and mediation between expatriate executives, trade unionists, state officials, workers, etc., allows them to mobilize these various actors for the benefit of the mining project despite their diverging interests. At the same time, it has negative 
consequences on the relations that HR managers have with their colleagues. While expatriate executives suspect them of being on the side of workers, the workers regard them as expatriate managers' collaborators. As a result, they tend to be isolated in the company, and when a crisis such as a strike or a mass lay-off occurs they are very often deemed responsible for it.

\section{Conclusion}

The aim of this article was to shed some light on the work of middle managers in foreign mining companies established in the global South. Few studies in the anthropology of mining deal with this category of employees, and the broader social science literature on middle managers is essentially on well-established corporations in the global North. It does not allow, therefore, to capture the specific experience of the HR managers of this study, who work for foreign mining companies developing new mining projects in Congo - a country of the global South. Who are they? What difficulties do they face? What do they do to mining projects? To answer these questions, this article proposed to study them as company brokers and to build on the anthropological literature on brokerage to analyze various aspects of their work.

Like the state and development brokers, HR managers act as intermediaries between an external organization and various local stakeholders. To access their position, and retain it, they acquired various organizational, legal, and cultural skills through a process of learning by doing. This position grants them a certain authority in Congolese society, as they are deemed to control access to jobs in mining companies. However, as they are not part of the expatriate executive team, their presence in this position is precarious: it depends to a large extent on their ability to retain their superiors' trust by demonstrating their skills, their loyalty and their cosmopolitanism. Eager to show that they deserve this trust, Congolese HR managers take an active part in the organizational changes that mining companies put in place, and strive to serve their employers' best interests. In this respect, they can be regarded as the agents of their own society's dependency on global capitalism (Bayart, 1993, 2000).4 This extraversion strategy however comes with a certain price. Deemed responsible for mining companies' labour policies, they can arouse resentment among the workers, who sometimes target them personally for retaliation.

The literature on brokers operating around mining projects can nevertheless be criticized for reproducing the image of the mining corporation as an actor in itself. By studying the everyday work of HR managers, this article provided an inside view of how mining companies work and localize their operations. From this perspective, mining projects are not merely negotiated from the outside, by local brokers interacting with a monolithic corporation, but also from within, by various categories of workers - especially those who are responsible for representing the company, coordinating its projects locally, dealing with state authorities, etc. 
Indeed, even though they often play a key role in the establishment of new mining projects, HR managers are only company brokers among others, whose responsibility is limited to labour-related issues. To understand how transnational mining projects are negotiated locally in a more comprehensive way, the scope of the analysis sketched above would need to be extended to other categories of middle managers. In doing so, the aim is to open the black box of mining companies so as to better understand how mining capitalism is generated out of the work practices, the social networks, and the ethical projects of the mine employees who play a strategic role at the project level (see Bear, 2015; Bear et al., 2015; Tsing, 2015). Far from being an external abstract force that is instrumentalized, resisted, or supported by leaders in the local political arena, mining projects are continuously co-produced by various local actors within and outside companies, and this from the very first step investors take in the country. [AQ1]

\section{Declaration of conflicting interests}

The author(s) declared no potential conflicts of interest with respect to the research, authorship, and/or publication of this article.

\section{Funding}

The author(s) disclosed receipt of the following financial support for the research, authorship, and/or publication of this article: This article was written as part of the WORKINMINING project led by Benjamin Rubbers at the Université de Liège. This project has received funding from the European Research Council (ERC) under the European Union's Horizon 2020 research and innovation programme (grant agreement $\mathrm{n}^{\circ}$ 646802). The ideas developed in this article reflect only the author's view. The ERC is not responsible for any use that may be made of the information it contains.

\section{Notes}

1. To anonymize informants, all the names in this article are pseudonyms.

2. HR managers are characterized as company brokers to underscore the fact that they perform various tasks (they recruit workers, negotiate with trade unions, organize mass layoffs, etc.) on behalf of foreign mining companies. As such, they differ from the labour brokers who operate on the labour market outside mining companies. The use of this term has to be understood more broadly in view of the main argument of the article, i.e. that middle managers play a key role in the localization of foreign companies, and hence in the development of capitalism in the global South.

3. On the historical significance of autochthony in the former Katanga province (see Bakajika, 1997; Dibwe Dia Mwembu, 2006; Gobbers, 2016).

4. Bayart $(1993,2000)$ proposes to study dependency not as a structure imposed by foreign powers, but as a process in which local power figures take an active part. His work stresses the significance of such extraversion practices in power strategies in Africa. The role of the HR managers of this study can thus be viewed as part of a broader repertoire of cultural practices that has a long history on the continent. 


\section{ORCID iD}

Benjamin Rubbers (DD https://orcid.org/0000-0002-2399-7937

\section{References}

घロ (2009) [AQ2]

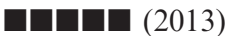

口ص (2019)

口[घ (2020)

Bailey FG (1963) Stratagems and Spoils: A Social Anthropology of Politics. Oxford: Blackwell.

Bakajika TB (1997) Epuration Ethnique en Afrique. Les 'Kasaiens'. Paris: L'Harmattan.

Ballard C and Banks G (2003) Resource wars: The anthropology of mining. Annual Review of Anthropology 32(1): 287-313.

Bayart J-F (1993) The State in Africa. The Politics of the Belly. London: Longman.

Bayart J-F (2000) Africa in the world: A history of extraversion. African Affairs 99(395): $217-267$.

Bear L (2015) Navigating Austerity: Currents of Debt along a South Asian River. Stanford: Stanford University Press.

Bear L, et al. (2015) Gens: A feminist manifesto for the study of capitalism. Theorizing the Contemporary. In: Fieldsights. Available at: https://culanth.org/fieldsights/gens-a-femi nist-manifesto-for-the-study-of-capitalism (accessed 25 July 2020).

Bierschenk T, Chauveau J-P and Olivier de Sardan J-P (2000) Courtiers en Développement. Les Villages Africains en Quête de Projets. Paris: Karthala \& APAD.

Blok A (1969) Peasants, patrons and brokers in Western Sicily. Anthropological Quarterly 42(3): $155-170$.

Boissevain J (1974) Friends of Friends: Networks, Manipulators and Coalitions. Oxford: Blackwell.

Bouffartigue P and Gadéa C (2001) Sociologie Des Cadres. Paris: La découverte.

Burawoy M (1972) The Colour of Class on the Copper Mines: From African Advancement to Zambianization. Manchester: Manchester University Press.

Cohen A and Comaroff JL (1976) The management of meaning: On the phenomenology of political transactions. In: Kapferer B (ed.) Transaction and Meaning: Directions in the Anthropology of Exchange and Symbolic Behavior. Philadelphia, PA: Institute for the Study of Human Issues, pp.87-107.

Cuvelier J and Geenen S (2019) Local elites' extraversion and repositioning: Continuities and changes in Congo's mineral production networks. The Extractive Industries and Society 6(2): 390-398.

Dalton M (1959) Men Who Manage. Fusions of Feeling and Theory in Administration. New York: Wiley and Sons.

Dibwe Dia Mwembu D (2001) Bana Shaba Abandonnés Par Leur Père: structures de L'autorité et Histoire Sociale de la Famille Ouvrière au Katanga. 1910-1997. Paris: L'Harmattan.

Dibwe Dia Mwembu D (2006) La réharmonisation des rapports entre les katangais et les kasaïens dans la province du Katanga (1991-2005). Anthropologie et Sociétés 30(1): $117-136$.

Fallers L (1955) The predicament of the modern African chief: An instance from Uganda. American Anthropologist 57(2): 290-305. 
Finn J (1998) Tracing the Veins. Of Copper, Culture and Community from Butte to Chuquicamata. Berkeley: University of California Press.

Geertz C (1960) The Javanese Kijaji: The changing role of a cultural broker. Comparative Studies in Society and History 2(2): 228-249.

Geschiere P and Nyamnjoh F (2000) Capitalism and autochthony: The seesaw of mobility and belonging. Public Culture 12(2): 423-452.

Gluckman P, Mitchell J and Barnes J (1949) The village headman in British Central Africa. Africa 19(2): 89-106.

Gobbers E (2016) Ethnic associations in Katanga province, the democratic republic of Congo: Multi-tier system, shifting identities and the relativity of autochthony. The Journal of Modern African Studies 54(2): 211-236.

Goldthorpe J (1982) The service class, its formation and future. In: Giddens A and Mackenzie G (eds) Social Class and the Division of Labour. Cambridge, UK: Cambridge University Press, pp.162-185.

Goldthorpe J (1995) The service class revisited. In: Butler T and Savage M (eds) Social Change and the Middle Classes. London: UCL Press, pp.313-329.

Golub A (2014) Leviathans at the Gold Mine. Creating Indigenous and Corporate Actors in Papua New Guinea. Durham, NC: Duke University Press.

Golub A and Rhee M (2013) Traction: The role of executives in localising global mining and petroleum industries in Papua New Guinea. Paideuma 59: 215-236.

Gonzales N (1972) Patron-client relationships at the international level. In Strickon A and Greenfield SM (eds) Structure and Process in Latin America. Albuquerque: University of New Mexico Press, pp.178-209.

Gordon R (1977) Mines, Masters and Migrants. Life in a Nambian Mine Compound. Johannesburg: Ravan Press.

Hannerz U (1996) Transnational Connections. Culture, People, Places. London: Routledge.

Hassard J, McCann L and Morris J (2007) At the sharp end of new organizational ideologies. Ethnography and the study of multinationals. Ethnography 8(3): 324-344.

Hassard J, McCann L and Morris L (2009) Managing in the Modern Corporation: The Intensification of Managerial Work in the UK, USA and Japan. Cambridge, UK: Cambridge University Press.

Ho K (2009) Liquidated. An Ethnography of Wall Street. Durham: Duke University Press. Jackall R (1988) Moral Mazes: The World of Corporate Managers. New York: Oxford University Press.

James D (2011) The return of the broker: Consensus, hierarchy and choice in South African land reform. Journal of the Royal Anthropological Institute 17(2): 318-338.

Kahola O (2015) L'accès à l'emploi à lubumbashi. Autrepart 74: 241-258.

Kalonji Wa Mpoyo J (2016) Langues et réinstallation des populations dans le secteur minier au Katanga (RDC). Cas de la Société Tenke Fungurume Mining. Unpublished PhD Thesis, University of Lubumbashi.

Kunda G (1992) Engineering Culture: Control and Commitment in a High-Tech Corporation. Philadelphia: Temple University Press.

Kuper A (1970) Gluckman's village headman. American Anthropologist 72(2): 355-358.

Lindquist J (2015) Anthropology of brokers and brokerage. In: Wright JD (ed.) International Encyclopaedia of the Social and Behavioral Sciences. Amsterdam: Elsevier, pp.870-874.

Mair LP (1936) Chieftainship in modern Africa. Africa 9(3): 305-316. 
Manson A and Mbenga B (2003) 'The richest tribe in Africa': Platinum-Mining and the Bafokeng in South Africa's North West Province, 1965-1999. Journal of Southern African Studies 29(1): 25-47.

Mayer A (1967) Patrons and brokers: Rural leadership in four overseas Indian communities. In: Freedman M (ed.) Social Organization and Peasant Societies. New York: Routledge, pp.167-188.

Moodie DT and Ndatshe V (1994) Going for Gold: Men, Mines, and Migration. Berkeley: University of California Press.

Mosse D and Lewis D (2006) Theoretical approaches to brokerage and translation in development. In: Mosse D and Lewis D (eds) Development Brokers and Translators. The Ethnography of Aid and Agencies. Bloomfield, CT: Kumarian Press, pp.1-26.

Nash J (1993[1979]) We Eat the Mines and the Mines Eat Us. Dependency and Exploitation in Bolivian Tin Mines. New York: Columbia University Press.

Negi R (2010) The mining boom, capital, and chiefs in the 'new Copperbelt'. In: Fraser A and Larmer M (eds) Zambia, Mining and Neoliberalism. Boom and Bust on the Globalized Copperbelt. New York: Palgrave MacMillan, pp.209-236.

Rajak D (2011) In Good Company: An Anatomy of Corporate Social Responsibility. Stanford, CA: Stanford University Press.

Renner K (1978[1953]) the service class. In: Bottomore T and Goode P (eds) Austro Marxism. Oxford: Oxford University Press, pp. 249-251.

Simmel G (1950) The Sociology of Georg Simmel. New York: Free Press.

Stovel K and Shaw L (2012) Brokerage. Annual Review of Sociology 38(1): 139-158.

Swidler A and Watkins SC (2017) A Fraught Embrace. The Romance and Reality of AIDS Altruism in Africa. Princeton: Princeton University Press.

Tsing A (2015) The Mushroom at the End of the World. On the Possibility of Life in Capitalist Ruins. Princeton: Princeton University Press.

Watson T (1994) In Search of Management. Culture, Chaos and Control in Managerial Work. London: Routledge.

Welker M (2014) Enacting the Corporation. An American Mining Firm in Post-Authoritarian Indonesia. Berkeley: University of California Press.

\section{Author Biography}

Benjamin Rubbers obtained his Ph.D. thesis from the Université Libre de Bruxelles and the Ecole des Hautes Etudes en Sciences Sociales in 2006. He is currently Professor of Social anthropology at the Université de Liège, Lecturer at the Université Libre de Bruxelles, and Research Associate at the Society, Work, and Development Institute of the University of Witwatersrand. He is the author of several books and articles on the Congolese copperbelt, where he does research since 1999. His research interests focus on work, mining, capitalism, and the local state in Africa. His last publication is a book co-edited with Alessandro Jedlowski, Regimes of Responsibility in Africa. Genealogies, rationalities and conflicts, Oxford and New York, Berghahn books. 